\title{
Iranian Nuclear Aspirations and Strategic Balancing in the Middle East:
}

\section{Challenging Conventional Wisdom}

\author{
Stephen Ellis and Andrew Futter
}

Stephen Ellis is a doctoral candidate and Dr. Futter is a senior lecturer in the Department of Politics and International Relations at the University of Leicester, UK.

With a few notable exceptions, ${ }^{1}$ it has become almost conventional wisdom to assume that a nuclear Iran is bad for its immediate neighbors, the wider Middle East region, and even the world. ${ }^{2}$ Such logic suggests that even an Iran with a nascent nuclear program would be emboldened in its meddling in Middle Eastern geopolitical affairs, present a serious, perhaps existential, threat to Israel and others, and could potentially lead to a nuclear-proliferation cascade among its immediate regional rivals. There is almost certainly some truth to these claims - and few people see an Iran armed with nuclear weapons as a good thing or something that should be welcomed. That said, much of the current debate has ignored or glossed over some of the other important geopolitical dynamics that have been driven by Iranian actions during the past decade: actions that have in fact been broadly positive for regional security and stability. As a result, if a comprehensive deal on the nuclear programme cannot be reached by the June 30 deadline, the strategic implications of latent or even a nuclear-armed Iran may not be as catastrophic as some have suggested and more subtle than many fear.

While much has been said and written about the potentially destabilizing nature of an Iranian nuclear weapon - and in particular the possibility of regional nuclear proliferation or even an Israeli-Iranian military conflict — far less attention has been paid to how current Iranian actions are changing and reconstituting strategic relationships across the Greater 
Middle East. Indeed, in a region where ever-changing geopolitical dynamics have constantly shaped perceived (often ephemeral) national-security requirements, we are again seeing novel alliances develop in the wake of a perceived shared threat, namely the possibility of a nuclear-armed Iran. We can see this on two distinct levels: (1) between Israel and the Arab states, and (2) in inter-Arab (Sunni) state relations. In fact, it could be argued that the region is as stable as it has been for a long time, notwithstanding the recent wars in Iraq and Afghanistan and the current challenge posed by ISIS. These relationships seem set to deepen as the search continues for a durable solution to the Iranian challenge in the wake of the April 2 interim agreement, and they may well be creating the conditions for a more stable and enduring future regional environment. Essentially, by causing widespread concern among its geopolitical neighbors, the Iranian nuclear program has served to induce greater regional stability in a number of particular instances. The result is that any type of future nuclear deal will necessarily come with certain political costs alongside the more widely discussed strategic benefits.

\section{THE IRANIAN CHALLENGE}

Since 2002, the majority of scholarly attention has focussed on the potentially destabilizing effects of Iranian nuclear aspirations for the Middle East region. Notwithstanding the work of Kenneth Waltz ${ }^{3}$ and a few others, conventional wisdom holds that Iran must be prevented from joining the nuclear club. However, while the Iranian nuclear challenge is the latest in a long line of revisionist developments in the Middle East, ${ }^{4}$ it is perhaps the first that fully affects all states, irrespective of religion, politics and geostrategic outlook (apart from the creation of Israel in 1948). As a direct result, a number of considerable geopolitical transformations and reorganizations have taken place in the region during the past decade in order to balance the perceived threat of a future nuclear capable Iran. Indeed, as will be 
explained below, these newly forged relationships appear more durable than similar manifestations in the past.

Far from a recent development, the Iranian nuclear program can actually be traced back to the 1950s, when it was initiated as part of U.S. President Dwight D. Eisenhower's Atoms for Peace initiative. ${ }^{5}$ The Tehran nuclear research reactor was declared operational as long ago as 1967. U.S. and Western European support for Iran's development of civilian nuclear technology continued until the revolution of 1979, when the Islamic Republic replaced the Western-friendly $\underline{S}$ hah. It is believed that, for the next two decades, Iran continued limited research into the full spectrum of nuclear capabilities, including possible weaponization. However, while concerns about Iranian nuclear intentions never went away during the 1980s and 1990s, ${ }^{6}$ it was not until 2002 that the international community woke up to the very real possibility of a nuclear-armed Iran. The Iranian dissident Alireza Jafarzadeh revealed to the world at that time the existence of an Iranian uranium-enrichment facility at Natanz and a heavy-water reprocessing plant at Arak. ${ }^{7}$ Both are regarded as key facilities for possible future weaponization.

Since then, various spokesmen have denied that Iran intended to try to produce a nuclear weapon, arguing instead that the nuclear program is for domestic civilian purposes (which it is entitled to under the Nuclear Non-Proliferation Treaty, NPT). ${ }^{8}$ As Supreme Leader Ayatollah Ali Khamenei declared in 2006:

The West knows very well that we are not seeking to build nuclear weapons. Nuclear weapons are against our political and economic interests and our Islamic beliefs. Therefore, the Islamic Republic will not fear the uproar and will continue on the path of scientific progress relying on its principles and the world cannot influence the will of our people. ${ }^{9}$ 
However, the international community — notably the International Atomic Energy Agency (IAEA), the United States and especially Israel remain unconvinced that the program is entirely peaceful. In spite of this, Iran remains a signatory of the NPT (signed in 1968) unlike India, Israel, North Korea and Pakistan (all possessing nuclear weapons ${ }^{10}$ ), which are not.

The Iranian position is complicated by the central bargain at the heart of the NPT. Essentially the treaty seeks to aid the development of nuclear technology for civilian purposes, such as power generation and medical research, but at the same time forbids any member from building or acquiring nuclear weapons. The problem is that what is required for civilian nuclear power - up to 20 percent enriched uranium 235 - uses broadly the same techniques as that needed for a nuclear bomb: roughly 90 percent enriched uranium 235 . While the uranium fissile material is not the only thing needed for a bomb, the fact that Iran has demonstrated the ability to enrich uranium at all presents the possibility that it could enrich to weapons-grade. Because of this, Iran is currently described as a "latent" nuclear power, one that could — if it chose to — produce a nuclear bomb within a relatively short space of time. As Wyn Bowen and Jonathan Brewer point out:

... it remains far from clear what, if any, timelines the regime has in mind for future possible options such as crossing additional technical thresholds, including enriching uranium to higher levels and developing or even testing a nuclear weapon, or additional diplomatic manoeuvring such as breaking out of the NPT. ${ }^{11}$

It is this uncertainty and disagreement over what constitutes an acceptable level of "breakout risk" that is at the heart of the current standoff, although the clear importance of the postAhmadinejad leadership of Hassan Rouhani (former chief nuclear negotiator in 2003) must 
be factored into this equation. Indeed, former French Ambassador to Iran Francois Nicoullaud has suggest that "...the actions I believe he took in 2003 raise hopes that as president of the Islamic Republic he will be able to find and implement a negotiated solution for the continuing nuclear crisis." 12

In November 2013, Iran agreed to a deal with the $\mathrm{P} 5+1^{13}$ to suspended uranium enrichment in return for much-needed sanctions relief. Under the so-called Geneva Agreement, Iran temporarily agreed to limit levels of uranium enrichment (to a maximum of 5 percent U235), cease building any new enrichment or reprocessing facilities, and open up its nuclear infrastructure to inspection by the IAEA. ${ }^{14}$ Initially, the deal was planned to last for six months, designed to provide space for a more comprehensive bargain. In early April 2015, a second "interim deal" was agree between the US, EU and Iran, whereby Iran agreed $\underline{\text { to; dilute or ship abroad its stockpile of enriched uranium; cease fissile material production at }}$ Fordow; render the Arak reactor incapable of producing weapons grade plutonium, and agree $\underline{\text { to heavy international scrutiny at Natanz. In return, most nuclear related sanctions against }}$ Iran would be dropped, but only once the IAEA confirms that these obligations have been fulfilled. ${ }^{15}$ While the deal has been heralded as a great breakthrough, a number of significant issues and complications remain to be addressed before the 30 June deadline for a comprehensive agreement. ${ }^{16}$ At the time of writing, However, at the time of this writing, no comprehensive pact has been agreed on, but negotiations continue in earnest. Iran probably has enough low-enriched uranium to convert to weapons grade in order to make a nuclear bomb if it chose to and is believed to have worked on various weaponization and warhead designs. ${ }^{17}$ As a result, the international community remains deeply concerned about the trajectory of developments over the past decade inside Iran and what this may mean for the future of the region. 
The Iranian nuclear program has been viewed almost unequivocally as a dangerous and destabilizing development and has already led to widespread planning for the "worst case" scenario: an Iranian nuclear weapon. As Ray Takeyh and James Lindsay explain:

The nightmare scenario that could be unleashed by Iran's nuclearization is easy to sketch. Israel would go on a hair-trigger alert-ready to launch a nuclear weapon at a moment's notice putting both countries minutes away from annihilation. Egypt, Saudi Arabia, and Turkey would scramble to join the nuclear club. The Nonproliferation Treaty (NPT) would collapse, unleashing a wave of nuclear proliferation around the globe. ${ }^{18}$

The threat is perhaps most pressingly felt in Israel, especially given the rhetoric of former President Mahmoud Ahmadinejad that Israel should be "wiped off the map."19 While the anti-Israeli tone is calmer now, Jerusalem remains very wary of developments inside Iran and has not ruled out a pre-emptive strike, should certain "red-lines" be crossed. The most obvious "threat" of the Iranian nuclear program therefore concerns Israel, as Eric Edelman et al. explain:

The greatest concern in the near term would be that an unstable Iranian-Israeli nuclear contest would emerge, with a significant risk that either side would launch a first strike on the other despite the enormous risks and costs involved. ${ }^{20}$

In addition, there is a widely held perception that a nuclear-armed Iran would also be emboldened in its regional meddling, leading to broader instability and insecurity. Indeed, the prospect of a nuclear Iran does not sit well with a whole host of other regional actors, for a wide range of other strategic reasons: Jordan, Kuwait and Saudi Arabia in the west; the 
Persian Gulf monarchies to the south; Pakistan to the east; and to the north, Turkey. Iranian actions have crossed traditional geopolitical, religious and to some extent ethnic divides and united these disparate interests.

\section{REGIONAL REACTIONS, GROWING CONCERNS}

Iran's apparent progress on its nuclear program over the past decade has produced considerable unease across the Middle East, with Israel and many Sunni Arab states viewing the possibility of (Shia) Iran achieving either an actual or latent nuclear capability to represent a significant strategic challenge. While the specifics of the threat differ across regional actors, there is a common theme: Iranian nuclear aspirations will be detrimental both to individual state security and to broader regional stability. As a result, Iranian actions are driving many erstwhile enemies and competitors closer together in order to balance against the greater perceived threat.

For Israel, a nuclear-capable Iran would be a highly threatening strategic development. Its emergence would end the nuclear monopoly the Jewish state has enjoyed in the Middle East for the past four decades. There is the calculation in Jerusalem that such a development would significantly weaken Israel's power and prestige. ${ }^{21}$ There are also concerns in Israeli strategic and policy-making circles that a nuclear-capable Iran would be emboldened in its support for anti-Israeli Palestinian groups and Hezbollah, ${ }^{22}$ and that a nuclear Iran could prompt other states in the region to consider acquiring nuclear weapons themselves, resulting in further strategic challenges for the Jewish state. ${ }^{23}$

Given this Israeli threat perception, relations between Israel and Iran have grown increasingly hostile since 2002. Israel has led a range of international efforts to apply diplomatic pressure and economic sanctions against the Islamic Republic designed to scupper the nuclear program or at least slow it down. ${ }^{24}$ Various Israeli leaders have also made either 
tacit or overt threats to use military force against Iran's nuclear program. ${ }^{25}$ Similarly, especially under the presidency of Mahmoud Ahmadinejad (2005-13), Iran's rhetoric regarding Israel grew increasingly inflammatory. ${ }^{26}$ Iran has also sought, relatively successfully, to create diplomatic linkage between its nuclear program and Israel's position as the region's sole nuclear power through the issue of a Middle East Nuclear-Weapons-Free Zone. $^{27}$

Iran and Israel are also believed to have engaged in covert hostile acts against one another. A number of cyber-attacks that have caused considerable damage to Iran's nuclear program are believed to have been the work of Israel and the United States, most notably the Stuxnet virus discovered in June $2010 .^{28}$ There have also been a number of assassinations of Iranian scientists involved in the Iranian nuclear program; Israeli intelligence services are suspected of being behind these killings. ${ }^{29}$ In response, Iran has been implicated in a number of terrorist acts against Israeli targets in various parts of the world. ${ }^{30}$ It has also sought to bolster its support for Hezbollah and Palestinian nonstate actors, partly as a way of inflicting costs on Israel for its opposition to its nuclear program. ${ }^{31}$ In sum, although relations between Israel and Iran had been hostile during the 1990s, it was the exposure of Iran's nuclear program in 2002 that sparked the intense strategic competition of the past decade.

The Iranian nuclear program has also created considerable concern among the region's Sunni Arab governments. Although these states have been much less public in their criticism of the Iranian nuclear program, due primarily to the domestic and regional political factors, there is much evidence to suggest that they too view the prospect of a nuclear Iran as a significant strategic challenge or even an outright threat. Much like the Israelis, Sunni Arab strategists believe that a nuclear capable Iran would be emboldened within the region to more aggressively challenge their interests in places such as Iraq, Syria, Lebanon, Yemen, Bahrain and the Palestinian territories. ${ }^{32}$ There is also a concern among Sunni Arab governments that, 
if Iran demonstrated its nuclear capability overtly, this would win Tehran considerable support from the region's Arab publics, who would view a nuclear Iran as a welcome challenge to Israel's nuclear monopoly. ${ }^{33}$ The result has been an increasing effort by many Sunni Arab states to balance against Iran in order to undermine Tehran's progress on its nuclear program. Although Sunni Arab balancing behavior against Iran has been less overt than that conducted by Israel, there have nonetheless been a number of tangible instances. Most notably, the Sunni Arab states have not publicly opposed economic sanctions and diplomatic pressure against Iran over its nuclear program. In fact, many Sunni Arab states have privately been staunch supporters of the sanctions regime and diplomatic pressure. ${ }^{34}$

Egypt, Jordan and Saudi Arabia, in particular, have individually and collectively sought to exploit their close relationship with the United States in order to try to convince Washington to take robust action against Iran's nuclear program. Saudi Arabia has also sought to weaken Iran's economy — and therefore its ability to pursue its nuclear program by maintaining relatively high oil production in a bid to drive down prices. ${ }^{35}$ Iran has responded by undertaking a more confrontational approach toward the Sunni Arab states, especially prior to the outbreak of the Syrian civil war in 2011. Tehran has sought to make it harder for Sunni Arab governments to take robust action against its nuclear programme by seeking support for its aspirations on the Arab street. ${ }^{36}$ Needless to say, such Iranian overtures were met with considerable suspicion and unease by Sunni Arab governments, and this served to further perpetuate and intensify growing Sunni-Arab-Iranian tensions and competition. As this reveals, the Iranian nuclear question has played a key role in driving tension and competition between Iran and the Sunni Arab states over the past decade. Of course, the Iranian nuclear program has not been the only factor undermining their relations, but it has been a critical factor and key source of division between Tehran and the Sunni Arab states. 


\section{NEW STRATEGIC RELATIONS AND THE GROWTH OF REGIONAL STABILITY}

While the Iranian nuclear issue continues to be a highly destabilizing dynamic with regard to Israeli-Iranian and Iranian-Sunni-Arab relations, it has also produced many important stabilizing regional effects. In particular, the perception of the Iranian nuclear program as a momentous and growing strategic threat has led directly to increased cooperation and coordination among the Sunni Arab states, something that has historically been difficult to achieve. Perhaps of even greater significance, the Iranian nuclear programme has also led to tangible and effective cooperation and coordination between Israel and the Sunni Arab states. In 2013, for example, the Israeli state budget accidentally disclosed a secret diplomatic mission in the Persian Gulf, a mission that many analysts considered designed to foster covert cooperation between Israel and the Sunni Arab states regarding the Iranian nuclear question. ${ }^{37}$ Indeed, from 2002 to the present, there has been a noticeable growth in cooperation and coordination among the Sunni Arab states and between the Sunni Arab states and Israel on this issue.

The increased cooperation has been driven by the widely held perception that Iran has been making important nuclear progress, that Tehran seeks an actual or latent nuclear capability, and — most critically — that, following the Iraq War, the United States alone may no longer be willing or able to successfully prevent Iran from achieving a nuclear capability. ${ }^{38}$ This shared perception has induced cooperation between Israel and the Sunni Arab states in a number of important and different ways. In particular, there have been indications of intelligence sharing between Israel and a number of Sunni Arab countries regarding Iran and its nuclear programme. ${ }^{39}$ In fact, such cooperation has extended beyond Sunni Arab states that recognize Israel and have relations with the Jewish state, to include Sunni Arab states that have no official relations with Israel. For example, there have been 
reports of Israeli intelligence services cooperating with their Saudi counterparts, ${ }^{40}$ and an exposed diplomatic cable revealed that Bahrain had been sharing intelligence with Israel about Iran. ${ }^{41}$ Most important, the disclosed diplomatic cable also demonstrated how such intelligence cooperation has led to an improvement in Israeli-Bahraini relations more generally. Indeed, Bahrain has also softened its criticism of Israel, no longer publicly referring to Israel as the "Zionist entity." 42

Beyond intelligence sharing, Israel's military capability, and its stated willingness to use it, has been seen in Arab capitals as a valuable way of putting pressure on the European Union and the United States to take robust diplomatic and economic action against Iran, even if they would not, in fact, welcome an actual Israeli military operation due to the implications it would have for their own domestic political fortunes. ${ }^{43}$ Similarly, from an Israeli perspective, Arab diplomatic pressure on the Iranian nuclear issue has been seen as giving greater legitimacy to Israel's calls for international sanctions and diplomatic pressure. ${ }^{44} \mathrm{~A}$ clear example of such Israeli-Sunni-Arab cooperation can be detected in the credible and recurring media reports that Saudi Arabia had agreed to allow access to its airspace for any military operation against Iran's nuclear program; this has not been denied by Israel and only half-heartedly by Riyadh. ${ }^{45}$ While this does not mean that such an eventuality would come to pass or that Saudi Arabia has even given Israel such permission, what the episode does reveal is the two states' usefulness to one another on this issue and the growing awareness of this fact in both states' capitals. $\frac{46}{}$

For both parties, reports that Israel and the Arab states have discussed and agreed on potential military plans, provide an effective way of pressurising the international community to take action against Iran. Cooperation between Israel and the Arab states would increase the feasibility (and therefore likelihood) of a possible Israeli strike against Iranian nuclear facilities. Indeed, the Sunni Arab states' growing tacit cooperation with Israel was also shown 
in 2007 , following an Israeli airstrike against a potential Syrian nuclear facility. ${ }^{47}$ In particular, following that strike, there was no vocal condemnation by the Sunni Arab states nor any discernible downturn or destabilization of Israeli-Sunni-Arab relations. In part, this reflected the fact that the Sunni Arab states welcomed and benefited from action against Syria's nuclear facilities. However, bound up in Israel's military operation and the Sunni Arab reaction to it was Iran and its nuclear program. In particular, the Sunni Arab states can be seen to have signaled to Israel, Iran and the international community that, while they currently have little appetite for Israeli military action against Iran due to domestic political concerns, this does not mean that the Sunni Arab governments would automatically oppose or try to prevent a military operation by Israel against Iran in the future.

In a similar regard, there have been many reports of Israel and the Sunni Arab states working in conjunction with one another in response to the interim deal between the international community and Iran over its nuclear program in $2013 .{ }^{48}$ Both Israel and the Sunni Arab states have been highly sceptical of the deal, fearing that Iran could renege on its promises and use it to make further nuclear progress. As a result, Israel and the Sunni Arab states sought to undermine the negotiations and, when that failed, they cooperated in an effort to ensure that the international community and Iran strictly and comprehensively followed the terms laid out. As The New York Times's Thomas Friedman reported:

Diplomats and ministers from Israel and the Israel lobby have been working Congress, while officials from Arab Gulf states have been telling the Obama administration directly the same message: how much they oppose the proposed deal that Secretary of State John Kerry and the foreign ministers of France, Britain, Russia, China and Germany have drafted to trade limited sanctions relief in return for Iran starting to roll back its nuclear program. ${ }^{49}$ 
Friedman went on to say, "Never have I seen Israel and America's core Arab allies working more in concert to stymie a major foreign policy initiative of a sitting U.S. president." ${ }^{, 5}$

A further example of the Iranian nuclear program's inducing Israeli-Sunni-Arab cooperation are the reports that Israel may look to extend its anti-missile system to neighboring Egypt and Jordan in light of the threat from Iran. ${ }^{51}$ While such a proposal has not (yet) materialized and only includes certain Sunni Arab states, the very fact that such possibilities are being discussed by high-level figures provides evidence of how the Iranian nuclear program and the potential future threat are serving to deepen Israeli-Sunni-Arab cooperation. Indeed, if the anti-missile system were to be expanded to Egypt and Jordan, this would provide clear evidence of substantial cooperation between Israel and certain Arab states to counteract the perceived threat from Iran. Furthermore, given that Israeli-Egyptian ties have been somewhat strained following the outbreak of the Arab Spring in 2011, if this development serves to "warm" Israeli-Egyptian relations more generally, it provides a further example of induced stability and cooperation among regional state actors.

The Iranian nuclear challenge has also deepened and improved cooperation among the Sunni Arab states, particularly those of the Gulf Cooperation Council (GCC). Over the past decade, these states have diplomatically, politically and militarily demonstrated a high degree of cooperation and coordination, something difficult to achieve or maintain in the past. ${ }^{52}$ Indeed, throughout the 1990s and early 2000s, the Sunni Arab states of the GCC had struggled to find a common direction for the organization, as many member states were hesitant to deepen the organisation's role and remit. Many of the smaller states were reluctant to increase their security ties within the organization due to concerns about Saudi Arabia's hegemonic intensions within the GCC. ${ }^{53}$ However, in response to the threat posed by Iran and its nuclear program, the states of the GCC have acted with far greater purpose and unity over 
the past decade. There has been increased cooperation on intelligence sharing, defence coordination and diplomatic engagement with regard to the Iranian nuclear program. ${ }^{54}$

This growing inter-GCC cooperation has been replicated across the wider Middle East. From 2002 until the toppling of Egyptian president Hosni Mubarak in 2011, Saudi Arabia and Egypt cooperated and coordinated extensively on the nuclear issue, and their governments remain committed to working together to prevent regional instability. ${ }^{55}$ Similarly, Saudi Arabia, Egypt and Jordan have worked in conjunction with one another diplomatically in order to push and prompt the major international powers — particularly the United States — to take robust action against Iran. ${ }^{56}$ As a result, and though it has certainly served to destabilize Israeli-Iranian and Arab-Iranian relations, the Iranian nuclear program has had a number of stabilizing effects across the Middle East.

While such cooperation and coordination has sometimes been tacit and subtle, it has also been tangible. Therefore, the Iranian nuclear program can be seen to have created and induced a number of important stabilizing dynamics within the region. It is highly probable that such cooperation and coordination will continue (and deepen) in the event of Iran's achieving an actual or latent nuclear capability. Given their current perception of the Iranian nuclear program, it is highly likely that Israel or the Sunni Arab states would view a future nuclear-armed Iran as a much more serious threat, and therefore as the basis for continued diplomatic, intelligence and defense cooperation.

Of course, this not to suggest that a nuclear-capable Iran would be an entirely stabilizing development. Tehran could become emboldened and a destabilizing force across the Middle East, and would likely lead to further deterioration in Israeli-Iranian and SunniArab-Iranian relations. However, it is essential not just to analyse the likely foreign-policy trajectory of a nuclear-capable Iran, but also to be cognizant of the wider regional dynamics 
and interstate relations that have stabilized and improved as a result of the Iranian nuclear issue more broadly.

\section{A NUCLEAR DEAL AND THE FUTURE REGIONAL BALANCE}

Since the exposure of Iran's clandestine nuclear program in 2002, policy makers from a number of prominent states and agencies have sought to reach a comprehensive deal to prevent weaponization. There have been a number of diplomatic initiatives involving a range of international actors. Successive U.S. administrations have grappled with the issue of Iran's nuclear program and intentions, and the European Union (EU) and Russia have also become heavily involved in the diplomatic process. ${ }^{57}$ However, so far at least, a comprehensive deal has not been brokered that would be acceptable to Iran, the region's major Middle Eastern states and the wider international community. Interestingly, while the possible ramifications of a nuclear Iran for regional security has received considerable attention and scrutiny, the implications of a comprehensive nuclear deal for Middle Eastern stability has received far less scholarly analysis. Instead, there is a widely held tacit assumption that a nuclear Iran would not be a stabilizing force. However, given the current cooperation that has taken hold among many major Middle Eastern states in response to the Iranian nuclear program, there is much evidence to suggest that a comprehensive nuclear agreement could, in fact, have certain wider destabilizing implications.

It is certainly possible that a comprehensive nuclear deal would go some way toward improving Iranian-Sunni-Arab relations by defusing some current major tension. Similarly, a comprehensive nuclear deal that fully satisfied and reassured Israel might also lead to reduced Israeli-Iranian antagonism. This is not to say that these dynamics would be completely transformed, but rather that an issue that drives hostility and competition would 
be removed, and this would likely result in a number of stabilizing benefits. However, a comprehensive nuclear deal (if indeed possible) could also entail certain destabilizing consequences. In particular, the regional cooperation generated as a result of the Iranian nuclear program could potentially falter or reverse entirely if a comprehensive nuclear deal were brokered between Iran and the international community. The Sunni Arab states would likely differ between those that sought to use the opportunity to reintegrate Iran into the regional order and normalize relations and those that still viewed even a non-nuclear Iran to be a significant military and political threat. In particular, Qatar and Oman are likely to lead the calls for normalizing Sunni-Arab-Iranian relations; Egypt, Jordan and especially Saudi Arabia are still likely to view Iran as representing a potent regional challenge. Therefore, a comprehensive nuclear deal could potentially have major implications for politics and could possibly undermine the recent diplomatic coordination. Instead, it may create significant dividing lines between Sunni Arab states regarding their positions and policies toward the Islamic Republic.

An Iranian nuclear deal is also likely to remove an important basis for Israeli-SunniArab cooperation. Certain Arab states might seek a broader Arab-Iranian rapprochement and could use the opportunity afforded by a deal to press more forcibly for international pressure on Israel to relinquish its nuclear arsenal and create a nuclear-free Middle East. ${ }^{58}$ Such calls would naturally serve as a source of disagreement and tension between Israel and the Sunni Arab states. Furthermore, although some Arab states would continue to view Iran as a threat — despite its no longer pursuing a nuclear capability — it is unlikely that they would see much utility in continued deep cooperation with Israel. For states such as Saudi Arabia, Bahrain, Kuwait or the UAE, a non-nuclear Iran would be considered primarily as a political and ideological threat, due to the challenges it presents to their domestic stability and role in the region. As a result, the Sunni Arab states would have little incentive to continue to align 
with Israel militarily. In fact, cooperation with Israel could prove detrimental to their political and ideological competition with Iran.

As a result of these potentially destabilizing consequences, and while a comprehensive deal that curtails the Iranian nuclear program should be welcomed and viewed as potentially broadly stabilizing for the Middle East, it should not be seen as a panacea. We must be aware of the wider geostrategic implications of such an agreement. A deal would certainly bolster the NPT and nuclear non-proliferation norms more generally and likely improve relations between Iran and certain Middle Eastern states. However, it is also likely that such an accord would undermine the rapprochement and deepening links that have developed over the past decade in the region. A comprehensive agreement should not be viewed as a zero-sum outcome.

\section{CONCLUSION}

It is perhaps a cliché to say that the Middle East is a complex region, but the ostensible pursuit of nuclear weapons by Iran has further complicated an already volatile part of the world, and in some unexpected ways. While it may be unpopular to point this out, there is evidence that the Iranian nuclear program has had some benefits for the region over the past decade. Primarily, it has helped facilitate a new period of stability based upon the relationships that have been forged to address the shared concern about Iran among a diverse range of states - a manifestation of classical power-balancing theory. Indeed, mutual concern about Iran has allowed former adversaries and erstwhile enemies to put aside some of their differences and address what is seen to be a much larger shared threat. The most obvious manifestation of this is between Israel and the Sunni Arab world, but it is also taking place along more traditional nation-state lines and between different Sunni Arab regimes. It 
could be that, far from the proliferation domino effect predicted by some or the chaos of an emboldened Iran by others, the current crisis might have provided a certain level of stability that has been impossible to achieve through other mechanisms, despite extensive high-level diplomatic engagement.

Accordingly, while a comprehensive deal _ acceptable to all - curtailing the Iranian nuclear program should be welcomed, we must be aware that failure to reach an agreement would not be a zero-sum outcome. Indeed, it is arguable that no deal might be better than a very weak deal that is seen to reward Iran for its behaviour. ${ }^{59}$ For a mixture of reasons, the continuation of the status quo whereby Iran retains a latent nuclear capability — or even achieves full weaponization - may not be as bad as conventional wisdom would lead us to believe. A deal to curtail Iranian nuclear ambitions would certainly bolster the NPT and nuclear non-proliferation norms more generally, and is likely to improve relations between Iran and the international community, but it is also possible that such a deal would undermine the rapprochements and deepening links that have developed over the past decade in the region between erstwhile traditional foes. In the long run, a comprehensive deal might actually be to the detriment of broader regional stability.

\footnotetext{
${ }^{1}$ See, for example, Kenneth Waltz, "Why Iran Should Get the Bomb," Foreign Affairs 91, no. 4 (2012): 2-5; or Christopher Hobbs and Matthew Moran, Explaining Regional Responses to a Nuclear Iran: Nuclear Dominoes? (Palgrave Macmillan: 2013).

${ }^{2}$ See, for example, Matthew Kroenig, "Time to Attack Iran: Why a Strike Is the Least Bad Option," Foreign Affairs 91, no. 1 (2012): 76-86; and Eric Edelman, Andrew Krepinevich and Evan Braden Montgomery, "The Dangers of a Nuclear Iran — The Limits of Containment," Foreign Affairs 90, no. 1 (2011): 69-81.
} 
${ }^{3}$ Kenneth Waltz, "Why Iran Should Get the Bomb": 2-5.

${ }^{4}$ The most prominent examples of such balancing behavior includes the establishment and maintenance of a largely unsuccessful coalition of Arab states that sought to prevent Israel from achieving hegemony in the Levant region of the Middle East; the alliance between Israel and Iran during the 1960s and 1970s, which sought to counteract the mutual threat posed to both powers by the Arab states, and particularly the rising power of Iraq, with the alliance continuing into the 1980s despite the Iranian revolution and the emergence of theocratic regime in Tehran; the alignment between Iraq and the conservative Arab states of the Persian Gulf against Iran during the 1980s, with Arab balancing behavior becoming especially intense at times when Iran appeared likely to be victorious over Iraq, which would have resulted in transforming Iran into the preeminent power in the Persian Gulf; and the more recent formation of a diverse regional coalition following Iraq's invasion and occupation of Kuwait in 1990, which sought to prevent Iraq emerging as the lead state in the Persian Gulf.

${ }^{5}$ The Atoms for Peace program was a U.S.-led initiative to supply civilian nuclear equipment for schools, hospitals and research throughout the world, begun in the early 1950s.

${ }^{6}$ See, for example, Shahram Chubin, "Does Iran Want Nuclear Weapons?" Survival 37, no. 1 (1995): 86-104.

${ }^{7}$ Alireza Jafarzadeh, The Iran Threat: President Ahmadinejad and the Coming Nuclear Crisis, (Palgrave MacMillan: 2008).

${ }^{8}$ See, for example, Iranian President Hassan Rouhani's statement to the United Nations General Assembly, September 24, 2013, http://gadebate.un.org/sites/default/files/gastatements/68/IR_en.pdf.

${ }^{9}$ Nazila Fathi, “Iran's Ayatollah Affirms Peaceful Nuclear Plans,” New York Times, January 19, 2006, http://www.nytimes.com/2006/01/19/international/middleeast/19iran.html?_r=0. 
${ }^{10}$ Israel operates a policy of "nuclear opacity," but is widely believed to have possessed a working nuclear arsenal since the 1970s. On this see Avner Cohen, The Worst Kept Secret: Israel's Bargain with the Bomb (Columbia University Press: 2010).

${ }^{11}$ Wyn Bowen and Jonathan Brewer, "Iran’s Nuclear Challenge: Nine Years and Counting," International Affairs 87, no. 4 (2011): 923.

${ }^{12}$ Francois Nicoullaud, "Rouhani and the Iranian Bomb," New York Times, July 26, 2013, http://www.nytimes.com/2013/07/27/opinion/global/rouhani-and-the-iranian-bomb.html.

${ }^{13}$ China, France, Germany, Russia, the United Kingdom and the United States.

${ }^{14}$ Anne Gearan and Joby Warrick, “Iran, World Powers Reach Historic Nuclear Deal,” Washington Post, November 23, 2013, http://www.washingtonpost.com/world/national-security/kerry-in-genevaraising-hopes-for-historic-nuclear-deal-with-iran/2013/11/23/53e7bfe6-5430-11e3-9fe0fd2ca728e67c_story.html.

\section{${ }^{15}$ US Department of States, "Parameters for a Joint Comprehensive Plan of Action Regarding the} Islamic Republic of Iran's Nuclear Program”, April 2 2015, http://www.state.gov/r/pa/prs/ps/2015/04/240170.htm ${ }^{16}$ See Colum Lynch \& John Hudson, "Iran, World Powers Strike Tentative Nuclear Accord", Foreign Policy, April 2 2015, http://foreignpolicy.com/2015/04/02/world-readies-for-breakthrough-on-iran-nuclear$\underline{\text { talks/ }}$

${ }^{17}$ Julian Borger, "Iran Nuclear Report: IAEA Claims Tehran Working on Advanced Warhead," Guardian, November 7, 2011, http://www.theguardian.com/world/2011/nov/07/iran-working-onadvanced-nuclear-warhead.

${ }^{18}$ Ray Takeyh and James Lindsay, “After Iran Gets the Bomb: Containment and Its Complications," Foreign Affairs 89, no.2 (2010): 38.

${ }^{19}$ Ewen MacAskill and Chris McGreal, "Israel Should Be Wiped Off Map, Says Iran’s President," Guardian, October 27, 2005, http://www.theguardian.com/world/2005/oct/27/israel.iran. 
${ }^{20}$ Eric Edelman, Andrew Krepinevich and Evan Braden Montgomery, "The Dangers of a Nuclear Iran," Foreign Affairs (2011): 67.

${ }^{21}$ Trita Parsi, Treacherous Alliance: The Secret Dealings of Israel, Iran and the U.S. (Yale University Press, 2007), 88 .

${ }^{22}$ Michael Oren, "Seven Existential Threats," Commentary (May 2009), http://www.commentarymagazine.com/article/seven-existential-threats/.

${ }^{23}$ David Blair, “Iran's Nuclear Programme May Spark Middle East Weapons Race,” Telegraph, May 20, 2008, http://www.telegraph.co.uk/news/worldnews/middleeast/iran/1994117/Irans-nuclearprogramme-may-spark-Middle-East-weapons-race.html.

${ }^{24}$ Isabel Kershner, "Israeli Foreign Ministry Calls for More Sanctions on Iran,” New York Times, September 27, 2012, http:/www.nytimes.com/2012/09/28/world/middleeast/israeli-foreign-ministrycalls-for-more-sanctions-on-iran.html?_r=0.

25 “Israeli PM Threatens to Strike Iran,” Al Jazeera, July 17, 2013, http://www.aljazeera.com/news/middleeast/2013/07/2013714214528446397.html.

${ }^{26}$ Ali Ansari, "Iran under Ahmadinejad: The Politics of Confrontation (Routledge, 2007), 55.

${ }^{27}$ Ladane Nasseri and Jonathan Tirone, "Iran Backs Nuclear Free Middle East in Dig at Israeli Arsenal," Bloomberg, February 19, 2013, http://www.bloomberg.com/news/2013-02-19/iran-backsnuclear-free-middle-east-in-dig-at-israeli-arsenal.html.

${ }^{28}$ Christopher Williams, "Stuxnet: Cyber Attack on Iran Was Carried Out by Western Powers and Israel," Daily Telegraph, January 21, 2011, http://www.telegraph.co.uk/technology/8274009/StuxnetCyber-attack-on-Iran-was-carried-out-by-Western-powers-and-Israel.html.

29 "U.S. Pressuring Israel to Stop Killing Iran Nuclear Scientists," Jerusalem Post, February 3, 2014, http://www.jpost.com/Diplomacy-and-Politics/US-pressuring-Israel-to-stop-killing-Iran-nuclearscientists-343977. See also, Siegfried S Hecker and Abbas Milani, "Ending the Assassination and Oppression of Iranian Nuclear Scientists," Bulletin of the Atomic Scientists 71:1 (2015), 46-52. 
${ }^{30}$ Ely Karmon, “Analysis / Iran and Hezbollah's Terror Escalation against Israel," Haaretz, July 22, 2012, http://www.haaretz.com/news/diplomacy-defense/analysis-iran-and-hezbollah-s-terrorescalation-against-israel-1.452953.

${ }^{31}$ Israel Ministry of Foreign Affairs, "Iran and Syria As Strategic Support for Palestinian Terrorism," September 30, 2011, http://www.mfa.gov.i1/MFA/MFAArchive/2000_2009/2002/9/Iran\%20and\%20Syria\%20as\%20Strate gic\%20Support $\% 20$ for $\% 20$ Palestinia.

${ }^{32}$ Phillip Robins, "The War for Regime Change in Iraq," in International Relations of the Middle East, ed. Louise Fawcett (Oxford University Press, 2009), 299.

${ }^{33}$ Following the outbreak of the "Arab Spring," and especially Iran's support for the Syrian government during the Syrian civil war, the possibility of Iran winning support among Arab publics through its nuclear program has diminished but still remains a realistic possibility. See René Rieger, "The Military Option in the Iranian Nuclear Crisis," International Relations Security Network, June 12, 2012, http://www.isn.ethz.ch/Communities-and-Partners/Partner-

Network/Detail/?lng=en\&id=143691.

${ }^{34}$ See Tariq Khaitous, “Arab Reactions to a Nuclear-Armed Iran,” Policy Focus 2004, (Washington Institute for Near East Policy, June 2009), http://www.washingtoninstitute.org/uploads/Documents/pubs/PolicyFocus94.pdf.

${ }^{35}$ Steve Hargreaves, "Low Oil Prices: A Tool to Control Iran,” CNN Money, February 11, 2010, http://money.cnn.com/2010/02/11/news/international/iran/index.htm.

${ }^{36}$ Stephen Ellis, "Iran, the Arab Street and Avoiding a Military Strike," E-international Relations, May 31, 2013, http://www.e-ir.info/2013/05/31/iran-the-arab-street-and-avoiding-a-military-strike/.

${ }^{37}$ Yossi Melman, “Bahrain King Boasted of Intelligence Ties with Israel," Haaretz, April 8, 2011, http://www.haaretz.com/print-edition/news/haaretz-wikileaks-exclusive-bahrain-king-boasted-ofintelligence-ties-with-israel-1.354728. 
38 "U.S. Army Chief: Iraq War Has Sapped Ability to Fight Iran," Haaretz, October 22, 2010, http://www.haaretz.com/news/u-s-army-chief-iraq-war-has-sapped-ability-to-fight-iran-1.231692.

${ }^{39}$ See Helene Cooper, "Converging Interests May Lead to Cooperation between Israel and Gulf States," New York Times, March 31, 2014, http://www.nytimes.com/2014/04/01/world/middleeast/converging-interests-may-lead-to-cooperationbetween-israel-and-gulf-states.html?_r=0.

${ }^{40}$ Tzvi Ben Gedalyahu, "Saudi Arabia Funds Mossad Anti-Iran Operations,” Israel National News, October 28, 2012, http://www.israelnationalnews.com/News/News.aspx/161407\#.U15kPPmSwuc.

${ }^{41}$ Yossi Melman, "Bahrain King Boasted of Intelligence Ties with Israel."

${ }^{42}$ Ibid.

43 "Sunday Times: Israel, Saudi Arabia Cooperating to Plan Possible Iran Attack," Haaretz, November 17, 2013, http://www.haaretz.com/news/diplomacy-defense/1.558512.

${ }^{44}$ Aaron Kalman, “Top Minister: Makes Sense for Israel, Arabs to Cooperate on Iran,” Times of Israel, October 3, 2012, http://www.timesofisrael.com/top-minister-makes-sense-for-israel-arabs-tocooperate-on-iran/.

${ }^{45}$ Hugh Tomlinson, "Saudi Arabia Gives Israel Clear Skies to Attack Iranian Nuclear Sites," The Times, June 12, 2010, http://www.timesonline.co.uk/tol/news/world/middle_east/article7148555.

${ }^{46}$ See for example, Asher Orkaby, "Rivals With Benefits: Israel and Saudi Arabia's Secret History of Cooperation", Foreign Affairs, March 13 2015, http://www.foreignaffairs.com/articles/143252/asherorkaby/rivals-with-benefits

${ }^{47}$ Uzi Mahnaimi, Sarah Baxter and Michael Sheridan, "Israelis Blew Apart Syrian Nuclear Cache," The Times, September 16, 2007,

http://www.timesonline.co.uk/tol/news/world/middle_east/article2461421.ece.

${ }^{48}$ Thomas Friedman, “Let’s Make a Deal,” New York Times, November 19, 2013, http://www.nytimes.com/2013/11/20/opinion/friedman-lets-make-a-deal.html?_r=0. 
${ }^{49}$ Ibid.

${ }^{50}$ Ibid.

${ }^{51}$ Dan Williams, "Israel Open to Joint Missile Defence with Jordan, Egypt,” Reuters, March 10, 2014, http://www.reuters.com/article/2014/03/10/israel-missiles-idUSL6N0M72MI20140310.

${ }^{52}$ Michael Knights, "Rising to Iran's Challenge: GCC Military Capability and U.S. Security Cooperation,” The Washington Institute, June 2013, http://www.washingtoninstitute.org/policyanalysis/view/rising-to-irans-challenge-gcc-military-capability-and-u.s.-security-coopera.

53 'Saudi-Qatari Tensions and Implications for the Persian Gulf,' Yemen Times, April 1, 2014, http://www.yementimes.com/en/1768/opinion/3672/Saudi-Qatari-tensions-and-implications-for-thePersian-Gulf.htm.

${ }^{54}$ Michael Knights, “Rising to Iran's Challenge: GCC Military Capability and U.S. Security Cooperation."

${ }^{55}$ Joel Gulhane, "Egypt, Saudi Arabia Stress Importance of Coordination," Daily News Egypt, December 2, 2013, http://www.dailynewsegypt.com/2013/12/02/egypt-saudi-arabia-stressimportance-of-coordination/.

${ }^{56}$ Thomas Friedman, "Let's Make a Deal."

${ }^{57}$ Kelsey Davenport, "History of Official Proposals on the Iranian Nuclear Issue," Arms Control Association, January 2014, http://www.armscontrol.org/factsheets/Iran_Nuclear_Proposals.

${ }^{58}$ On this see Patricia Lewis, “A Middle East Free of Nuclear Weapons: Possible, Probable or Pipe Dream?" International Affairs 89, no. 2 (2013): 433-450.

${ }^{59}$ David Kenner, "Iran Deal Threatens to Upend a Delicate Balance of Power in the Middle East", Foreignpolicy.com, April 2 2015, http://foreignpolicy.com/2015/04/02/iran-deal-threatens-to-upend$\underline{\text { a-delicate-balance-of-power-in-the-middle-east-saudi-arabia-nuclear-deal/ }}$ 